\title{
Reconstruction of diagenetic history of ancient carbonate by LA-ICP-MS trace element mapping
}

\author{
Hu ANPING ${ }^{1,2}$, YANG HANAUAN ${ }^{1,2}$ LUOXIANYING $^{1,2}$
}

1. PetroChina Hangzhou Research Institute of Geology(HIPG), Xihu District, Hangzhou, China

2. Key Laboratory of Carbonate reservoirs, CNPC, Xihu

District, Hangzhou, China

(*Correspondence: huap_hz@petrochina.com.cn)

Traditional whole-rock or in-situ geochemical anlyses do not have sufficient resolution to deconvolute the complexity in the diagenetic environment of ancient carbonates with high heterogeneity. This presentation demonstrates a LA-ICP-MS trace element mapping technique that directly displays the planar distribution of trace elements in rock sections, and thus provides more detailed and comprehensive geochemical information useful for diagenetic reconstruction. The trace element mapping of the microbial carbonate samples from the Sinian Qigebulake Formation in northwestern Tarim Basin, China reveals four different types of dolomitic cements filling the reservoir space: 1) the fibrous rimmed cements that have similar elemental distribution of $\mathrm{Li}$, $\mathrm{Mn}, \mathrm{Fe}, \mathrm{Sr}, \mathrm{Ba}, \mathrm{Th}$ and $\mathrm{U}$ with the host rock, where the high $\mathrm{Mn}$ and $\mathrm{Fe}$ contents indicate a marine diagenetic environment, and the contrast in the $\mathrm{Mn}$ and $\mathrm{Fe}$ contents between the dark and light rims reveals frequent changes in sea level; 2) the leaf shaped cements where their homogeneous elemental distributions are consistent with relatively stable diagenetic environment, and their relatively low $\mathrm{Mn}$ and $\mathrm{Fe}$ contents reflect more meteoric freshwater influence; 3) the crystalline dolomite, the most common cement type, that has low $\mathrm{Sr}$ and $\mathrm{U}$ contents, indicating burial diagenetic environment; and 4) the last stage cements of hydrothermal dolomite with high strontium and low oxygen isotope values, filling the solution vugs. Based on the results of trace elemental mapping, as well as the carbonate $\mathrm{U}-\mathrm{Pb}$ dating, the depositional-diagenetic environment and history of the Sinian cabonates can be readily divided into six consequential stages, involving an Ediacarandeposition and early dolomitization, freshwater infitration, marine water controlled diagenesis, shallow burial, deep burial and late hydrothermal dolomitization. 